\title{
Antioxidant and antimicrobial activities of various extracts from Stachys cretica subsp. bulgarica Rech.f., Stachys byzantina K. Koch and Stachys thirkei K. Koch
}

\author{
Gizem Gülsoy Toplan 1,5 (D), Turgut Tașkın² (D), Emel Mataracı Kara ${ }^{3}$ (D) Gülay Ecevit Genç ${ }^{4}$ (D) \\ 'İstanbul University, Faculty of Pharmacy, Department of Pharmacognosy, İstanbul, Turkey \\ ${ }^{2}$ Marmara University, Faculty of Pharmacy, Department of Pharmacognosy, İstanbul, Turkey \\ ${ }^{3}$ Istanbul University, Faculty of Pharmacy, Department of Pharmaceutical Microbiology, İstanbul, Turkey \\ 4'stanbul University, Faculty of Pharmacy, Department of Pharmaceutical Botany, İstanbul, Turkey \\ ${ }^{5}$ Istinye University, Faculty of Pharmacy, Department of Pharmacognosy, İstanbul, Turkey
}

ORCID IDs of the authors: G.G.T. 0000-0002-0544-2532; T.T. 0000-0001-8475-6478; E.M.K. 0000-0003-4541-1893; G.E.G. 0000-0002-1441-7427

Cite this article as: Gulsoy Toplan, G., Taskin, T., Mataraci Kara, E., \& Ecevit Genc, G. (2021). Antioxidant and antimicrobial activities of various extracts from Stachys cretica subsp. bulgarica Rech.f., Stachys byzantina K. Koch and Stachys thirkei K. Koch. Istanbul Journal of Pharmacy, 51(3), 341-347.

\begin{abstract}
Background and Aims: Stachys L. species, which are members of the Lamiaceae family, have long been applied for their therapeutic benefits especially to cure cough, infection, genital tumors, ulcers, inflammatory illnesses, and wounds in Anatolian traditional medicine. In the current study, various extracts prepared from the aerial parts of Stachys cretica subsp. bulgarica Rech.f. (SC), Stachys byzantina K. Koch (SB), Stachys thirkei K. Koch and were tested for their in vitro antioxidant, antibacterial, and anticandidal properties.

Methods: The aerial parts of three Stachys species were sequentially extracted using $n$-hexane, chloroform, and methanol. Aqueous extracts of each sample was also prepared by infusion process. The total phenolic content of each extract was determined and the contribution of the biological activities in the samples was evaluated. To assess the antioxidant capacity, samples were studied using CUPRAC activity, DPPH• free radical scavenging, and FRAP methods. The antimicrobial activity of the extracts was tested against 7 bacteria and 3 yeast.

Results: The infusion and methanol extract exhibited the strongest antioxidant potential and also had the highest percentage of phenolics among the studied extracts. The $n$-hexane extracts of all studied species showed considerable antifungal activity with MIC values ranging from 312.5-78.12 $\mathrm{mg} / \mathrm{L}$.

Conclusion: According to our results, three Stachys species were found to be beneficial for their antioxidant and antimicrobial properties.

Keywords: Stachys, antioxidant activity, total phenolic, antimicrobial activity
\end{abstract}

\section{INTRODUCTION}

Plants have been evaluated for different purposes throughout humankind's history such as food, hunting, prevention and treatment of diseases, and preparation for spiritual ceremonies. Several studies have confirmed the beneficial properties of plants in

Address for Correspondence:

Gizem GÜLSOYTOPLAN, e-mail: eczgizemgulsoy@gmail.com, gizem.toplan@istinye.edu.tr

This work is licensed under a Creative Commons Attribution 4.0 International License. 
the pharmaceutical, food, and cosmetic industries and that has led to an increase in their economic value (Silva, \& Fernandes Júnior, 2010). In particular, Lamiaceae species offer a broad range of activities due to their rich chemical composition (Frezza, Venditti, Serafini, \& Bianco, 2019).

Stachys $L$. is classified as one of the most extensive genera of the Lamiaceae family, containing over 300 species with almost worldwide distribution (BilušićVundać, 2019; Tundis, Peruzzi, \& Menichini, 2014). The flora inTurkey is represented by approximately 90 species including 115 taxa, 54 of which are endemic (Akcicek, Dirmenci, \& Dündar, 2012). The species of Stachys are annual, perennial herbs or tiny shrubs with simple leaf segments that attach directly to the stem or are sessile. They are commonly known as 'Dağ Çayı' in Anatolian folk medicine and utilized as an appetizer, healer for digestive complaints, stimulant, antispasmodic, and also as carminative (Baytop, 1999; Goren, 2014). Ethnopharmacological usage of Stachys species is supported by several studies in the worldwide literature, mainly demonstrated by antibacterial, anti-Helicobacter pylori, anti-inflammatory, anticancer, and antioxidant properties (Salehi, Sonboli, \&Asghari, 2007; Khanavi et al., 2009; Goren et al., 2011; Tomou, Barda, \& Skaltsa, 2020; Tundis et al., 2014). The promising findings shown in research conducted on several antioxidant test systems also indicate the great potential for preventing diseases that correlate with the deficiency of antioxidant mechanisms (Erdemoglu, Turan, Cakıcı, Sener, \& Aydın, 2006; Kukić, Petrović, \& Niketić, 2006; Hajdari, Novak, Mustafa, \& Franz, 2012; Tundis, et al., 2014). The diversity in its pharmacological properties can be explained via its containing multiple classes of secondary metabolites in combination (Pieters \& Vlitenick, 2005). An extensive range of investigations have been conducted on the phytochemistry of Stachys species that have revealed the presence of iridoids, di- and triterpenes, alkaloids, phenylethanoid glycosides, flavonoids, phenolic acids, and essential oil (Kaya, Demirci, \& Baser, 2001; Asnaashari et al., 2010; Demirtas, Gecibesler, \& Yaglioglu, 2013; Tomou et al., 2020).

Free radicals have become of concern since they appear to play a role in a wide range of diseases and food deterioration (Fang, Yang, \& Wu, 2002). Multiple studies have indicated that the production of reactive oxygen species (ROS) and the resulting oxidative stress are important in the initiation and progression of many major disorders, including cancer and degenerative diseases (Valko et al., 2007). According to the literature, phenolic compounds have significant effects on the protection of degenerative disorders due to slowing down free radical reactions and reducing lipid oxidation (Toplan et al., 2017). Butylated hydroxytoluene $(\mathrm{BHT})$ and butylated hydroxyanisole $(\mathrm{BHA})$ are commonly employed in the foodservice industry as synthetic antioxidants to prevent oxidative degradation in prepared foods
(Branen, 1975). Because of the potentially harmful consequences of these agents, there has been a tremendous rise in international importance and utilization of plants for their antioxidant, anti-aging, and antimicrobial benefits, and besides, they have fewer adverse effects (Li et al., 2012). Therefore, this encourages researchers to investigate plants, especially those rich in phenolics, for their natural antioxidants which keep the human body healthy and preserve food from rotting.

Today, antibiotic resistance is a significant public health problem. There is substantial evidence of resistance to nearly all of the antimicrobial drugs now in use, and this evidence is growing (Kwapong, Soares, Teo, Stapleton, \& Gibbons, 2020). In recent decades, the amount of new antibacterial medications has decreased and the design and discovery of new antibacterial chemicals have become one of the key fields of antibacterial research (Coqueiro, Regasini, Stapleton, da Silva Bolzani, \& Gibbons, 2014). Another key issue in the food, beverage, cosmetic, and pharmaceutical industries is microbial contamination (Tiwari et al., 2009). Researchers worldwide are keen to discover new natural antimicrobial compounds in response to growing cases of microbe resistance to currently used preservatives. Numerous investigations have approved the promising antibacterial and antifungal characteristics of plant extracts as well as secondary metabolites (Pieters \& Vlietinck, 2005). Nowadays, a large percentage of prescribed medicines consist of plantbased products (Atanasov, Zotchev, Dirsch, \& Supuran, 2021).

Three Stachys species, namely Stachys cretica subsp. bulgarica, S. byzantina and S. thirkei whose traditional names are 'Kızıl Deliçay,', 'Bozkarabaş', and 'Kestere' respectively, are three of the most used species in Turkish traditional medicine; their infusions or decoctions are consumed as a tea by local people for mainly gastrointestinal problems (Satıl \& Acar, 2020). In the current study, the antioxidant and antimicrobial activities of different extracts obtained from the aerial parts of these three Stachys species were screened for their total phenolic content.

\section{MATERIALS AND METHODS}

\section{Plant material}

The aerial parts of Stachys cretica subsp. bulgarica (SC), S. byzantina and S. thirkei were collected from Saray-Güngörmez, Tekirdağ, and Kastamonu during the flowering stage. After that, the collected plants were dried at room temperature in a dark storeroom. Dried plant material was ground usinga laboratory mill before the experiments. Specimens were identified by one of us (Gulay, Ecevit-Genç) and vouchers were deposited in in Herbarium of Istanbul University Faculty of Pharmacy (ISTE). The herbarium number of each plant are given in Table 1.

Table 1. The location of the collected plants with herbarium number.

\begin{tabular}{|lcccc|}
\hline Species & Location & Date & Herbarium Number & Sample Code \\
\hline Stachys cretica subsp. bulgarica (SC) & Tekirdağ & 15.07 .2015 & ISTE 117262 & SC \\
Stachys byzantina (SB) & Ilgaz Yolu- Kastamonu & 02.08 .2015 & ISTE 117263 & SB \\
Stachys thirkei (ST) & Saray-Güngörmez & 15.07 .2015 & ISTE 117264 & ST \\
\hline
\end{tabular}




\section{Extraction of samples}

The aerial parts of each plant were crushed and extracted sequentially with $n$-hexane, chloroform, and methanol using a Soxhlet apparatus. A rotary evaporator was used to evaporate the solvents under reduced pressure, with a maximum temperature of $50^{\circ} \mathrm{C}$. Following solvent evaporation, the crude extracts were kept at $+4{ }^{\circ} \mathrm{C}$ until analysis and used in all studies.

The aqueous extracts of aerial parts of each plant were prepared by infusing $10.0 \mathrm{~g}$ of dried material in $200 \mathrm{~mL}$ of distilled water for $15 \mathrm{~min}$ at $80^{\circ} \mathrm{C}$. The infusion was filtered, and the filtrates were frozen and stored at $-80^{\circ} \mathrm{C}$ in an ultra-low degree freezer. After that, the solution was lyophilized, and the freezedried product was stored at $-20^{\circ} \mathrm{C}$ until the screening.

\section{Total phenolic content of the samples}

$4.5 \mathrm{~mL}$ of distilled water was added to $0.1 \mathrm{~mL}$ of the extracts produced at $0.5-5 \mathrm{mg} / \mathrm{mL}$ concentrations. The absorbance of a blue color after 2 hours at room temperature was measured at $760 \mathrm{~nm}$ against reference standards using $0.1 \mathrm{~mL}$ of FolinCiocalteu reagent (diluted $1 / 3$ with distilled water) and 0.3 $\mathrm{mL}$ of $2 \%$ carbonate solution. The total phenolic content was measured as milligram gallic acid equivalents per milligram of extract (Taskın, Taskın, \& Rayaman, 2018).

\section{Antioxidant capacity of the samples}

\section{The cupric reducing antioxidant capacity (CUPRAC)}

CUPRAC technique was used to assess the antioxidant capacity of the samples. $60 \mu \mathrm{L} \mathrm{Cu}$ (II) (1.10-2 M), neocuproine ethanolic solution (7.3.10-3 M), and $1 \mathrm{M}$ ammonium acetate buffer solution were added to a microplate well. The samples were diluted with solvent mixture of methanol:DMSO (2:1 v/v). $60 \mu \mathrm{L}$ of the diluted extracts and $10 \mu \mathrm{L}$ pure ethanol were added to the original mixture. The absorbance of the solution was measured at $450 \mathrm{~nm}$ against a reagent blank after ten seconds of vortexing. The Trolox equivalents (mM Trolox/mg extract) were used to calculate the CUPRAC values of the samples. (Apak, Güçlü, Özyürek, \& Karademir, 2004).

\section{DPPH radical scavenging activity}

The ability of free radical scavenging of the four different extracts was tested using the DPPH technique. To summarize, $240 \mathrm{~mL}$ of DPPH solution $(0.1 \mathrm{mM})$ was combined with $10 \mathrm{~mL}$ of extracts ( $5 \mathrm{mg} / \mathrm{mL}-0.5 \mathrm{mg} / \mathrm{mL}$ ) at varied concentrations. The combination was then held at room temperature for another 30 minutes before being used. Using a microplate reader set at $517 \mathrm{~nm}$, the absorbance of the mixture was measured in comparison to a standard (Wei et al., 2010).

\section{Reducing power capacity (FRAP technique)}

The FRAP technique was used to test the capacity of the samples ( $5 \mathrm{mg} / \mathrm{mL}-0.5 \mathrm{mg} / \mathrm{mL}$ concentrations) to reduce ferric ion. In brief, FRAP reagent $(3.8 \mathrm{~mL}$ ) was combined with samples $(0.2 \mathrm{~mL})$ and the absorbance of the combination was measured at $593 \mathrm{~nm} 4$ minutes later. The standard curve was made using $\mathrm{FeSO}_{4} .7 \times \mathrm{H}_{2} \mathrm{O}$, and the FRAP values of the samples were expressed in $\mathrm{mM} \mathrm{Fe}^{2+} / \mathrm{mg}$ extract (Benzie \& Strain, 1996).

\section{Antimicrobial activities of the samples}

Determination of minimum inhibitory concentrations (MICs)

Staphylococcus aureus ATCC 29213, S. epidermidis ATCC 12228, Enterococcus faecalis ATCC 29212, Pseudomonas aeruginosa ATCC 27853, Escherichia coli ATCC 25922, Klebsiella pneumoniae ATCC 4352, Proteus mirabilis ATCC 14153, Candida albicans ATCC 10231, C. parapsilosis ATCC 22019, and C. tropicalis ATCC 750 were used in this study for in vitro antimicrobial activities of various extracts obtained from three different Stachys species. The antimicrobial activity assay of the samples against these strains was determined using the broth microdilution technique as described by the Clinical and Laboratory Standards (CLSI, 1997; CLSI, 2020). The MIC was defined as the lowest concentration of antibiotics giving complete inhibition of visible growth. The following standard antibacterial and antifungal agents were used as standard compounds: Cefuroxime-sodium, cefuroxime, ceftazidime, amikacin, amphotericin B, and clotrimazole. RPMI-1640 medium for the yeast strain and Mueller-Hinton broth for bacteria were used as negative controls.

\section{Statistical analysis}

Results were expressed as the mean \pm standard deviation (SD) of three independent and parallel measurements. One-way analysis of variance (ANOVA) was performed, and significant differences between means were determined using Tukey's multiple comparisons test. Statistical significance was set at $p<0.05$.

\section{RESULTS AND DISCUSSION}

\section{The yield and total phenolic contents of the samples}

Aerial parts of Stachys cretica subsp. bulgarica, S. byzantina and S. thirkei were extracted successively using several solvents to obtain crude extracts and the results of fractions yielded and also their total phenolic content are demonstrated in Table 2.

Total phenolic compounds contained in plants were determined by the FCR method. Compared with other extracts, infusion and methanol extracts prepared from plants were found to have higher quantities of phenolic compounds. The total amount of phenolics contained in the methanol extracts prepared from three plants is as follows: SC methanol (0.101 mg GAE/mg extract)> SB methanol (0.090 mg GAE/mg extract) $>$ ST methanol (0.058 mg GAE/g extract)

In this investigation, it was discovered that methanol and infusion extracts prepared from aerial parts of the plants had significant amounts of phenolic compounds and, as a result, showed substantial biological activity, which is in line with the literature.

\section{Antioxidant capacity of the samples}

The antioxidant capacity of the samples was measured by CUPRAC activity, DPPH • free radical scavenging, and FRAP methods. The results of the three different methods aredemonstrated in Table 3. 
Table 2. The yield and total phenolic content of the extracts (beginning with $10 \mathrm{~g}$ of material).

\begin{tabular}{|lccc|}
\hline Samples & Extracts & Yield & Total phenolics \\
\hline Stachys cretica subsp. bulgarica (SC) & n-hexane & 0.1177 & $0.00237 \pm 0.00180$ \\
& chloroform & 0.194 & $0.0496 \pm 0.0014$ \\
Stachys byzantina (SB) & methanol & 1.6308 & $\mathbf{0 . 1 0 1 0 \pm 0 . 0 1 1 7}$ \\
& infusion & 0.224 & $\mathbf{0 . 0 6 8 4 \pm 0 . 0 0 5 8}$ \\
& n-hexane & 0.1157 & $0.0173 \pm 0.0109$ \\
Stachys thirkei (ST) & chloroform & 0.1903 & $0.0386 \pm 0.0062$ \\
& methanol & 2.3717 & $\mathbf{0 . 0 9 0 1 \pm 0 . 0 9 8}$ \\
& infusion & 0.3784 & $\mathbf{0 . 0 6 3 0 \pm 0 . 0 0 5 7}$ \\
& n-hexane & 0.1462 & $0.0032 \pm 0.0056$ \\
& chloroform & 0.1278 & $0.0134 \pm 0.0030$ \\
& methanol & 1.236 & $\mathbf{0 . 0 5 7 8 \pm 0 . 0 1 0 4}$ \\
\hline
\end{tabular}

Table 3. Antioxidant activity of the various extracts from three Stachys species.

\begin{tabular}{|c|c|c|c|}
\hline Samples & $\begin{array}{c}\text { DPPH } \\
\text { (mg AaE/mg extract) }\end{array}$ & $\begin{array}{c}\text { FRAP assay } \\
\left(\mathrm{mM} \mathrm{Fe}^{2+} / \mathrm{mg} \text { extract }\right.\end{array}$ & $\begin{array}{c}\text { CUPRAC } \\
\text { (mM trolox/mg extract) }\end{array}$ \\
\hline $\mathrm{SC}-\mathrm{H}$ & $0.00496 \pm 0.004288$ & $0.122 \pm 0.01^{9 *}$ & $0.055 \pm 0.00^{3 *}$ \\
\hline SC-C & $0.013456 \pm 0.000626$ & $0.337 \pm 0.02^{7 \star}$ & $0.097 \pm 0.00^{2 \star}$ \\
\hline SC-M & $0.062819 \pm 0.000371$ & $0.454 \pm 0.00^{7 *}$ & $0.102 \pm 0.00^{3 *}$ \\
\hline SC-I & $0.049691 \pm 0.01142$ & $0.459 \pm 0.00^{2 \star}$ & $0.097 \pm 0.00^{1 *}$ \\
\hline SB-H & $0.00231 \pm 0.001782$ & $0.197 \pm 0.03^{0 *}$ & $0.052 \pm 0.00^{4 *}$ \\
\hline SB-C & $0.004962 \pm 0.001384$ & $0.339 \pm 0.01^{2 *}$ & $0.072 \pm 0.00^{5 *}$ \\
\hline SB-M & $0.0627 \pm 0.000412$ & $0.476 \pm 0.00^{2 \star}$ & $0.098 \pm 0.00^{1 *}$ \\
\hline SB-I & $0.055988 \pm 0.000713$ & $0.434 \pm 0.00^{5 *}$ & $0.095 \pm 0.00^{4 *}$ \\
\hline ST-H & $0.00258 \pm 0.000879$ & $0.038 \pm 0.00^{6 *}$ & $0.051 \pm 0.00^{2 *}$ \\
\hline ST-C & $0.00609 \pm 0.000713$ & $0.331 \pm 0.03^{5 *}$ & $0.079 \pm 0.00^{2 \star}$ \\
\hline ST-M & $0.039118 \pm 0.005585$ & $0.363 \pm 0.03^{3 *}$ & $0.089 \pm 0.00^{6 *}$ \\
\hline ST-I & $0.05076 \pm 0.001029$ & $0.451 \pm 0.00^{5 *}$ & $0.092 \pm 0.004 *$ \\
\hline \multicolumn{2}{|l|}{ BHT } & $1.1 \pm 0.12$ & \\
\hline \multicolumn{2}{|l|}{$\mathrm{BHA}$} & & $1.622 \pm 0.12$ \\
\hline \multicolumn{4}{|c|}{$\begin{array}{l}\text { Values are mean of triplicate determination }(n=3) \pm \text { standard deviation; }{ }^{*} p<0.05 \text { compared with the positive control } \\
\text { H: } n \text {-hexane extracts, C: Chloroform extracts; M: Methanol extracts; I: Infusion; BHA: butylated hydroxyanisole; BHT: butylated hydroxytoluene; } \\
\text { AaE: ascorbic acid equivalent }\end{array}$} \\
\hline
\end{tabular}

The cupric reducing antioxidant capacity of infusion and methanol extracts of three plants were found to be quite similar in this investigation. The methanol extracts of the SB (0.098 $\mathrm{mM}$ trolox/mg extract) and SC (0.102 mM trolox/mg extract) plants, as well as the infusion of ST $(0.092 \mathrm{mM}$ trolox/mg extract) plant, were found to have the greatest CUPRAC value.

The methanol extract produced from SC (0.102 mM trolox/ mg extract) had a higher cupric reducing antioxidant capacity than the other extracts, according to the cupric reducing antioxidant capacity of the plants. When the cuprac values of all extracts were compared to the standard substance (1.622 mM trolox/mg extract), it was discovered that they had a reduced activity potential.

As a result of DPPH radical scavenging activities of the methanol extracts from SB (0.063 mg AaE/mg extract) and SC $(\mathbf{0 . 0 6 2}$ $\mathrm{mg} \mathrm{AaE} / \mathrm{mg}$ extract) plants, as well as the infusion extract from the ST (0.051 mg AaE/mg extract) plant, were shown to have a greater radical scavenging capability than the other extracts in the present investigation. When the plants utilized in this study were examined, it was discovered that the radical scavenging 
activity of the SB and SC was quite similar. In comparison to the two other species, ST exhibited to have low radical scavenging activity.

A general association between reductive capacity and the presence of antioxidant agents is that they break free radical chains by donating hydrogen atoms. Reducing power assays are commonly used to determine whether an antioxidant is capable of transforming a Fe ${ }^{+3}$ to $\mathrm{Fe}^{+2}$ (El Atki, et al., 2020). Hence, the FRAP assays were employed to determine the ferric reducing power of the samples. The FRAP values of infusion and methanol extracts produced from SB and SC were found to be extremely near to each other in the FRAP experiment. Infusion of SC (0.459 $\mathrm{mM} \mathrm{Fe}^{2+} / \mathrm{mg}$ extract) and ST (0.451 mM $\mathrm{Fe}^{2+} / \mathrm{mg}$ extract), as well as methanol extract of the SB (0.476 $\mathrm{mM} \mathrm{Fe}{ }^{2+} / \mathrm{mg}$ extract), showed to have greater iron (III) ion reducing power activity than other extracts. When the plants iron-reducing activities were evaluated, the methanol extract of SB was found to have the greatest FRAP value. All of the extracts obtained from the plants showed to have a lower iron reduction capacity than the positive control, $\mathrm{BHT}$ compound (1.1 $\mathrm{mM} \mathrm{Fe}^{2+} / \mathrm{mg}$ extract).

Numerous investigations confirmed not only the antioxidant potential of many Stachys species but also the rich diversity of their chemical composition many of which reduce free radical damage (Jassbi, Miri, Asadollahi, Javanmardi, \& Firuzi, 2014; Sarikurkcu, Kocak, Uren, Calapoglu, \& Tepe, 2016; Bahadori, Zengin, Dinparast, \& Eskandani, 2020). This is the first study to identify and compare the antioxidant capacity of different solvent extracts of these three species. It is well-known that the antioxidant capacities of extracts are influenced by many factors including extraction procedure, polarities of used solvents, and also polymorphic properties and diversity of the species (BilušićVundać, 2019; Tomou, et al., 2020). Thus, different types of complementary methods are recommended to evaluate the antioxidant potential of the extracts. Generally, the highest antioxidant activity is observed in polar extracts of plants such as methanol, infusion, and decoction due to containing high amounts of phenolic compounds (Ertas, \&Yener, 2020). As a result of the evaluation of the various solvents' extract from three Stachys species in several assays, infusion and methanol extracts showed the highest antioxidant capacity with the highest total phenolic content compared with the other extracts.

\section{Antimicrobial activity of the samples}

To provide comparable data for samples, the samples obtained from three Stachys species and prepared with various types of solvents were tested against a panel of three Gram-positive bacteria and four Gram-negative bacteria by using the broth micro dilutions technique according to the Clinical Laboratory Standards Institute (CLSI) recommendations (CLSI, 1997; CLSI, 2020). Well-known commercial antibiotics were used as the standard drugs and the minimal inhibitory concentrations (MIC) values compared with the standard drugs are presented in Table 4. The extracts exhibited moderate to mild antimicrobial activities compared with the standards. Nevertheless, infusion of all species was not shown to have any antimicrobial activity. Depending on the antibacterial results of all compounds, it was observed that all of the tested Stachys' samples displayed no inhibitory activity against any Gram-negative bacteria except methanol extract of SC for E. coli. In addition to this, n-hexane extracts of SCB also showed antimicrobial activity against tested Gram-positive bacteria with the MIC values ranging from 312.5 to $625 \mathrm{mg} / \mathrm{L}$.

Antifungal activity of each extract was tested against three pathogenic yeasts, namely C. albicans, C. parapsilosis, and C. tropicalis. Among all the extracts studied for antifungal potency, $n$-hexane extracts of each species showed strong activity against $C$. parapsilosis and C. tropicalis. The most resistant yeast against the samples was determined as C. albicans. The $n$-hexane extracts of SC and ST exhibited strong anticandidal activity

Table 4. The antimicrobial and antifungal activity of the various extracts from three Stachys species (MIC, $\mu \mathrm{g} / \mathrm{mL})$.

\begin{tabular}{|llllllllll} 
Strains & SC-H & SC-C & SC-M & SB-H & SB-C & SB-M & ST-H & ST-C & ST-M \\
\hline P. aeruginosa ATCC 27853 & $>2500$ & $>2500$ & $>2500$ & $>2500$ & $>2500$ & $>2500$ & $>2500$ & $>2500$ & $>2500$ \\
E. coli ATCC 25922 & $>2500$ & $>2500$ & 312.5 & $>2500$ & $>2500$ & $>2500$ & $>2500$ & $>2500$ & $>2500$ \\
K. pneumoniae ATCC 4352 & $>2500$ & $>2500$ & $>2500$ & $>2500$ & $>2500$ & $>2500$ & $>2500$ & $>2500$ & $>2500$ \\
P. mirabilis ATCC 14153 & $>2500$ & $>2500$ & $>2500$ & $>2500$ & $>2500$ & $>2500$ & $>2500$ & $>2500$ & $>2500$ \\
E. faecalis ATCC 29212 & $\mathbf{3 1 2 . 5}$ & $>2500$ & $>2500$ & $>2500$ & 156.2 & $>2500$ & $>2500$ & $>2500$ & $>2500$ \\
S. epidermidis ATCC 12228 & 625 & $>2500$ & $>2500$ & $>2500$ & $>2500$ & 1250 & $>2500$ & 625 & 625 \\
S. aureus ATCC 29213 & $>2500$ & $>2500$ & $>2500$ & $>2500$ & $>2500$ & $>2500$ & $>2500$ & $>2500$ & $>2500$ \\
C. albicans ATCC 10231 & $>2500$ & $>2500$ & $>2500$ & $>2500$ & $>2500$ & $>2500$ & $>2500$ & $>2500$ & $>2500$ \\
C. parapsilosis ATCC 22019 & $\mathbf{7 8 . 1 2}$ & $>2500$ & $>2500$ & 156.2 & $>2500$ & $>2500$ & $\mathbf{7 8 . 1 2}$ & $>2500$ & $>2500$ \\
C. tropicalis ATCC 750 & $\mathbf{1 5 6 . 2}$ & $>2500$ & $>2500$ & $\mathbf{3 1 2 . 5}$ & $>2500$ & $>2500$ & $>2500$ & $>2500$ & $>2500$ \\
\hline
\end{tabular}

$\mathrm{H}:$ - -hexane extracts, C: Chloroform extracts; M: Methanol extracts; I: Infusion

Reference compounds: Ceftazidime: $2.4 \mathrm{mg} / \mathrm{L}$ For $P$. aeruginosa, Cefuroxime-Na: $4.9 \mathrm{mg} / \mathrm{L}$ for E. coli and K. pneumoniae, Cefuroxime-Na:

$2.4 \mathrm{mg} / \mathrm{L}$ for P. Mirabilis, Cefuroxime-Na: $1.2 \mathrm{mg} / \mathrm{L}$ for $S$. aureus, Cefuroxime: $9.8 \mathrm{mg} / \mathrm{L}$ for S. epidermidis, Amikacin: $128 \mathrm{mg} / \mathrm{L}$ for E. faecalis, Clotrimazole: $4.9 \mathrm{mg} / \mathrm{L}$ C. albicans, Amphotericin B: $0.5 \mathrm{mg} / \mathrm{L}$ for C. parapsilosis, Amphotericin B: $1 \mathrm{mg} / \mathrm{L}$ for C. tropicalis. 
against C. parapsilosis with $78.12 \mathrm{mg} / \mathrm{L}$ MIC values whereas the $n$-hexane extracts of SB and SC exhibited moderate anticandidal activity against $C$. tropicalis with $\mathrm{MIC}$ values ranging from 312.5-156.2 mg/L. As to the antibacterial activity of chloroform extracts, E. faecalis and S. epidermis were found to be susceptible to the SB and ST samples.

According to the literature, the essential oil and extracts of Stachys species possess remarkable antimicrobial activity related to the polarities of extracts, composition of samples, and species' growing conditions (İşcan et al., 2012; Leblebici, Kaygusuz, Korkmaz, \& Darcan, 2016). Previously, the antimicrobial activity of essential oil from several Stachys species were investigated using the disc diffusion method and among them, considerable antifungal activity from the essential oil of Stachys cretica subsp. Bulgarica was observed against C. albicans (Goren et al., 2011). In another study, the $n$-butanolic and light petroleum extracts of Stachys cretica subsp. lesbiaca and S. cretica subsp. trapezuntica showed antifungal activity whereas no antibacterial activity was observed in either ethanol, dichloromethane, or ethyl acetate extracts (Şerbetçi et al., 2010). The methanol extracts of S. byzantina, S. inflata, S. lavandulifolia, and S. taxa were tested against Gram-positive bacteria and yeast, in contrast, in the other studies no antifungal activities were determined in the extracts whereas remarkable concentration-dependent antibacterial activity was determined in both disc diffusion and MIC methods (Saeedi, Morteza-Semnani, Mahdavi, \& Rahimi, 2008).

\section{CONCLUSION}

Interest in ethnopharmacology has recently increased due to the recent development of phytochemistry methodologies (Bremner \& Heinrich, 2002). Aromatic plants are of great potential for both antioxidant and antimicrobial activities owing to the rich synergy of different types of secondary metabolites (Tomou et al., 2020). In the present study, the antimicrobial and antioxidant activities of four type of extracts obtained from Stachys cretica subsp. bulgarica, S. byzantina and S. thirkei were carried out and their total phenolic contents were determined.

In several investigations was noticed that many progressive illnesses are related to the imbalance of oxidative stress in the body. Thus, finding alternative extracts or compounds in the plant kingdom becomes one of the most important targets in the scientific area. The present study results indicated that the polar extracts of all investigated Stachys species showed considerable antioxidant effects and also had high amounts of phenolic contents. Furthermore, the increased bacterial resistance is one of the significant global health concerns all around the world. As to the MIC values, the extracts of Stachys cretica subsp. bulgarica, and S. byzantina exhibited strong to moderate antimicrobial activity while the extracts of Stachys thirkei exhibited moderate to poor antimicrobial activity. Consequently, these findings highlight the value of these three Stachys species. But still more research into the chemical compositions, molecular mechanisms, and adverse impacts of extracts is needed to determine their potential.
Peer-review: Externally peer-reviewed.

Author Contributions: Conception/Design of Study- G.G.T., G.E.G.; Data Acquisition- G.G.T., T.T., E.M.K.; Data Analysis/Interpretation- G.G.T., T.T., E.M.K.; Drafting Manuscript- G.G.T.; Critical Revision of ManuscriptG.G.T., T.T., E.M.K., G.E.G.; Final Approval and Accountability- G.G.T., T.T. E.M.K., G.E.G.

Conflict of Interest: The authors have no conflict of interest to declare.

Financial Disclosure: Authors declared no financial support.

\section{REFERENCES}

Akcicek, E., Dirmenci, T., \& Dündar, E. (2012). Taxonomical notes on Stachys sect. Eriostomum (Lamiaceae) in Turkey. Turkish Journal of Botany, 36(3), 217-234.

- $\quad$ Apak, R., Güçlü, K., Özyürek, M., \& Karademir, S. E. (2004). Novel total antioxidant capacity index for dietary polyphenols and vitamins $C$ and $E$, using their cupric ion reducing capability in the presence of neocuproine: CUPRAC method. Journal of agricultural and food chemistry, 52(26), 7970-7981.

- $\quad$ Asnaashari, S., Delazar, A., Alipour, S. S., Nahar, L., Williams, A. S., Pasdaran, A., Mojarabi, M., Fathi Azad, F., \& Sarker, S. D. (2010). Chemical composition, free-radical-scavenging and insecticidal activities of the aerial parts of Stachys byzantina. Archives of Biological Sciences, 62(3), 653-662.

- Atanasov, A. G., Zotchev, S. B., Dirsch, V. M., \& Supuran, C. T. (2021). Natural products in drug discovery: Advances and opportunities. Nature Reviews Drug Discovery, 20(3), 200-216.

- Bahadori, M. B., Zengin, G., Dinparast, L., \& Eskandani, M. (2020). The health benefits of three Hedgenettle herbal teas (Stachys byzantina, Stachys inflata, and Stachys lavandulifolia)-profiling phenolic and antioxidant activities. European Journal of Integrative Medicine, 36, 101134.

- $\quad$ Baytop, T. (1999). Türkiye'de bitkiler ile tedavi: geçmişte ve bugün (2 ${ }^{\text {th }}$ ed.). Nobel Tip Kitabevleri.

- $\quad$ Benzie, I.F., Strain, J.J. (1996). The ferric reducing ability of plasma (FRAP) as a measure of "antioxidant power": the FRAP assay. Analytical Biochemistry, 239, 70-6.

- BilušićVundać, V. (2019). Taxonomical and phytochemical characterisation of 10 Stachys taxa recorded in the Balkan Peninsula flora: A review. Plants, 8(2), 32.

- Branen, A. L. (1975). Toxicology and biochemistry of butylated hydroxyanisole and butylated hydroxytoluene. Journal of the American Oil Chemists' Society, 52(2), 59-63.

- Bremner, P., \& Heinrich, M. (2002). Natural products as targeted modulators of the nuclear factor-KB pathway. Journal of Pharmacy and Pharmacology, 54(4), 453-472.

Clinical and Laboratory Standards Institute (CLSI), (1997). Reference Method for Broth Dilutions Antifungal Susceptibility Testing of Yeasts; Approved Standard-Second Edition, in Wayne, PA, USA.

- Clinical and Laboratory Standards Institute (CLSI), (2020). Performance Standards for Antimicrobial Susceptibility Testing, in, Clinical and Laboratory Standards Institute, 950 West Valley Road, Suite 2500, Wayne, Pennsylvania 19087, USA.

- Coqueiro, A., Regasini, L. O., Stapleton, P., da Silva Bolzani, V., \& Gibbons, S. (2014). In vitro antibacterial activity of prenylated guanidine alkaloids from Pterogynenitens and synthetic analogues. Journal of Natural products, 77(8), 1972-1975.

- $\quad$ Demirtas, I., Gecibesler, I. H., \& Yaglioglu, A. S. (2013). Antiproliferative activities of isolated flavone glycosides and fatty acids from Stachys byzantina. Phytochemistry Letters, 6(2), 209-214. 
- $\quad$ El Atki, Y., Aouam, I., El Kamari, F., Taroq, A., Lyoussi, B., Oumokhtar, B., \& Abdellaoui, A. (2020). Phytochemistry, antioxidant and antibacterial activities of two Moroccan Teucrium polium L. subspecies: preventive approach against nosocomial infections. Arabian Journal of Chemistry, 13(2), 3866-3874.

- Erdemoglu, N., Turan, N. N., Cakıcı, I., Sener, B., \& Aydın, A. (2006). Antioxidant activities of some Lamiaceae plant extracts. Phytotherapy Research, 20(1), 9-13.

- $\quad$ Ertas, A., \& Yener, I. (2020). A comprehensive study on chemical and biological profiles of three herbal teas in Anatolia; rosmarinic and chlorogenic acids. South African Journal of Botany, 130, 274281.

- $\quad$ Fang, Y. Z., Yang, S., \&Wu, G. (2002). Free radicals, antioxidants, and nutrition. Nutrition, 18(10), 872-879.

- $\quad$ Frezza, C., Venditti, A., Serafini, M., \& Bianco, A. (2019). Phytochemistry, chemotaxonomy, ethnopharmacology, and nutraceutics of Lamiaceae. In Studies in Natural Products Chemistry, 62, 125-178.

- Goren, A. C. (2014). Use of Stachys species (mountain tea) as herbal tea and food. Records of Natural Products, 8(2), 71.

- Goren, A. C., Piozzi, F., Akcicek, E., Kılıç, T., Çarıkçı, S., Mozioğlu, E., \& Setzer, W. N. (2011). Essential oil composition of twenty-two Stachys species (mountain tea) and their biological activities. Phytochemistry Letters, 4(4), 448-453.

- Hajdari, A., Novak, J., Mustafa, B., \& Franz, C. (2012). Essential oil composition and antioxidant activity of Stachys sylvatica L. (Lamiaceae) from different wild populations in Kosovo. Natural Product Research, 26(18), 1676-1681.

- Iş̧can, G., Demirci, B., Demirci, F., Göger, F., Kırımer, N., Köse, Y. B., \& Başer, K.H.C. (2012). Antimicrobial and antioxidant activities of Stachys lavandulifolia subsp. lavandulifolia essential oil and its infusion. Natural Product Communications, 7(9), 1934578 X1200700937.

- Jassbi, A. R., Miri, R., Asadollahi, M., Javanmardi, N., \& Firuzi, O. (2014). Cytotoxic, antioxidant and antimicrobial effects of nine species of woundwort (Stachys) plants. Pharmaceutical Biology, 52(1), 62-67.

- Kaya, A., Demirci, B., \& Baser, K. H. C. (2001). The composition of the essential oil of Stachys iberica subsp. stenostachya growing in Turkey. Chemistry of Natural Compounds, 37(4), 326-328.

- Khanavi, M., Hajimahmoodi, M., Cheraghi-Niroomand, M., Kargar, Z., Ajani, Y., Hadjiakhoondi, A., \& Oveisi, M. R. (2009). Comparison of the antioxidant activity and total phenolic contents in some Stachys species. African Journal of Biotechnology, 8(6), 1143-1147.

- Kukić, J., Petrović, S., \& Niketić, M. (2006). Antioxidant activity of four endemic Stachys taxa. Biological and Pharmaceutical Bulletin, 29(4), 725-729.

- Kwapong, A. A., Soares, S., Teo, S. P., Stapleton, P., \& Gibbons, S. (2020). Myristica lowiana Phytochemicals as Inhibitor of Plasmid Conjugation in Escherichia coli. Evidence-Based Complementary and Alternative Medicine, 2020, 1-6.

- Leblebici, S., Kaygusuz, Ö., Korkmaz, T., \& Darcan, C. (2016). The antimicrobial activities of the leaves of some endemic Stachys species spreading in West Anatolia, Turkey. Mitteilungen Klosterneuburg, 66(6), 18-28.

- $\quad$ Li, W. J., Nie, S. P., Liu, X. Z., Zhang, H., Yang, Y., Yu, Q., \& Xie, M. Y. (2012). Antimicrobial properties, antioxidant activity and cytotoxicity of ethanol-soluble acidic components from Ganoderma atrum. Food and Chemical Toxicology, 50(3-4), 689-694.
Pieters, L., \& Vlietinck, A. J. (2005). Bioguided isolation of pharmacologically active plant components, still a valuable strategy for the finding of new lead compounds. Journal of Ethnopharmacology, 100(1-2), 57-60.

- Saeedi, M., Morteza-Semnani, K., Mahdavi, M. R., \& Rahimi, F. (2008). Antimicrobial studies on extracts of four species of Stachys. Indian Journal of Pharmaceutical Sciences, 70(3), 403.

- Salehi, P., Sonboli, A., \& Asghari, B. (2007). Chemical composition of the essential oil of Stachys acerosa and its antibacterial and antioxidant activities. Chemistry of Natural Compounds, 43(3), 339341.

- $\quad$ Sarikurkcu, C., Kocak, M. S., Uren, M. C., Calapoglu, M., \& Tepe, A. S. (2016). Potential sources for the management global health problems and oxidative stress: Stachys byzantina and S. iberica subsp. iberica var. densipilosa. European Journal of Integrative Medicine, 8(5), 631-637.

Satıl, F., \& Acar, M. (2020). Ethnobotanical use of Stachys L. (Lamiaceae) taxa in Turkey. International Journal of Nature and Life Sciences, 4(2), 66-86.

Silva, C., \& Fernandes Júnior, A. (2010). Biological properties of medicinal plants: a review of their antimicrobial activity. Journal of venomous Animals and Toxins Including Tropical Diseases, 16, 402-413.

Şerbetçi, T., Demirci, B., Güzel, Ç. B., Kültür, Ş., Ergüven, M., \& Başer, K. H. C. (2010). Essential oil composition, antimicrobial and cytotoxic activities of two endemic Stachys cretica subspecies (Lamiaceae) from Turkey. Natural Product Communications, 5(9), $1934578 \times 1000500907$.

- Taşkın, D., Taşkın, T., \& Rayaman, E. (2018). Phenolic composition and biological properties of Achillea nobilis L. subsp. neilreichii (Kerner) Formanek. Industrial Crops and Products, 111, 555-562.

- Tiwari, B. K., Valdramidis, V. P., O'Donnell, C. P., Muthukumarappan, K., Bourke, P., \& Cullen, P. J. (2009). Application of natural antimicrobials for food preservation. Journal of Agricultural and Food Chemistry, 57(14), 5987-6000.

- Tomou, E. M., Barda, C., \& Skaltsa, H. (2020). Genus Stachys: A review of traditional uses, phytochemistry and bioactivity. Medicines, 7(10), 63.

- Toplan, G. G., Kurkcuoglu, M., Goger, F., İşcan, G., Ağalar, H. G., Mat, A., Başer, K.H.C. \& Sarıyar, G. (2017). Composition and biological activities of Salvia veneris Hedge growing in Cyprus. Industrial Crops and Products, 97, 41-48.

- $\quad$ Tundis, R., Peruzzi, L., \& Menichini, F. (2014). Phytochemical and biological studies of Stachys species in relation to chemotaxonomy: a review. Phytochemistry, 102, 7-39.

- Valko, M., Leibfritz, D., Moncol, J., Cronin, M. T., Mazur, M., \& Telser, J. (2007). Free radicals and antioxidants in normal physiological functions and human disease. The International Journal of Biochemistry \& Cell Biology, 39(1), 44-84.

- Wei, F., Jinglou, C., Yaling, C., Yongfang, L., Liming, C., Lei, P., Zhou, D., Liang, X., \& Ruan, J. (2010). Antioxidant, free radical scavenging, antiinflammatory and hepatoprotective potential of the extract from Parathelypterisnipponica (Franch.et Sav.) Ching. Journal of Ethnopharmacology, 130, 521-528. 